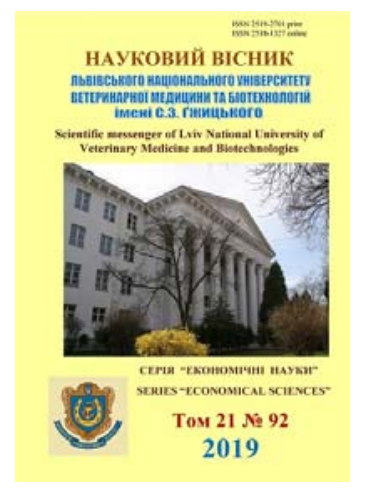

\section{Науковий вісник Дьвівського національного університету ветеринарної медицини та біотехнологій імені С.3. Гжицького. Серія: Економічні науки}

\author{
Scientific Messenger of Lviv National University \\ of Veterinary Medicine and Biotechnologies. \\ Series: Economical Sciences
}

UDC 159.92:159.9.018:37.013.

\title{
Animal therapy as a promising direction of human rehabilitation treatment
}

\author{
A.I. Labinskyi, M.R. Hrytsyna, B.V. Gutyj, H.B. Labinska \\ Stepan Gzhytskyi National University of Veterinary Medicine and Biotechnologies, Lviv, Ukraine
}

Article info

Received 04.02.2019

Received in revised form 06.03 .2019

Accepted 07.03.2019

Stepan Gzhytskyi National University of Veterinary Medicine and Biotechnologies Lviv, Pekarska Str., 50, Lviv, 79010, Ukraine.

Tel.: +38-096-469-70-10 E-mail: pharm-biology@lvet.edu.ua

\begin{abstract}
Labinskyi, A.I., Hrytsyna, M.R., Gutyj, B.V., \& Labinska, H.B. (2019). Animal therapy as a promising direction of human rehabilitation treatment. Scientific Messenger of Lviv National University of Veterinary Medicine and Biotechnologies. Series: Economical Sciences, 21(92), $160-164$. doi: $10.32718 /$ nvlvet-e9227
\end{abstract}

Animals therapy is one of the types of therapy, which includes the use of animals as a means of treatment. The purpose of such therapy is to improve the patient's social, emotional, or cognitive functions. It is distinguished directed animal therapy (the use of specially trained animals for developed therapeutic programs) and non-directional (interaction with animals at home). Animal therapy methods, in contrast to other rehab techniques, allow not only to reduce muscle tone, increase the volume of passive movements, acquire new active motor skills, and, in addition to kinesiological rehabilitation effects, is intended to perform the following functions: psycho-physiological function; psychotherapeutic function; rehabilitation function; function of satisfaction of the need for competence; self-realization function; communication function. Hypotherapy is one of the most effective methods of animal therapy. The restorative effect of horse riding for patients is based on the use of the function of motion, which has for man not only biological, but also social significance. Hippotherapy combines kinesitherapy, physiotherapy, cognitive action on the emotions and the psyche of the patient, contributes to the destruction of pathological efferent impulses. Dolphin therapy for the rehabilitation of children with post-traumatic stress syndrome, depression, emotional disorders, diseases of the locomotorium, etc., is actively developing in many countries, especially in the coastal countries, including Ukraine, since the 70s of the last century. The positive effect of felinotherapy in children with enuresis, logoneurosis, neurasthenia was established. Felinotherapy helps to lower blood pressure, normalizes the work of the heart, relieves articular and headaches. Cats accelerate recovery after injuries, cure internal inflammatory diseases. Canisterapy (treatment by dogs) is indicated for gout, rheumatism, liver and bladder disorders. In canisterapy, the breeds of companion dogs are most often used: labradors, collie, pugs etc. In addition to the described methods, there are still many methods of animal therapies. These are human contacts with reptiles, a dream on bees of honey bees, and others.

Key words: anilotherapy, hippotherapy, felinotherapy, canisteriography.

\section{Анімалотерапія - перспективний напрямок реабілітаційного лікування людини}

\author{
А.Й. Лабінський, М.Р. Грицина, Б.В. Гутий, Г.Б. Лабінська
}

Львівський національний університет ветеринарной медицини та біотехнологій імені С.З. Гжицького, м. Львів, Україна

\footnotetext{
Анімалотерапія є одною з видів терапї, яка включає в себе використання тварин, як засіб для лікування. Мета такої терапії полягає у поліпшенні соціальних, емочійних, або когнітивних функцій пацієнта. Розрізняють направлену анімалотерапію (використання спечіально навчених тварин за розробленими терапевтичними програмами) і ненаправлену (взаємодія з тваринами у домаиніх умовах). Методи анімалотерапї̈ на відміну від інших реабілітаційних методик дозволяють не тільки змениити м'язовий тонус, збільшити обсяг пасивних рухів, набути нових активних моторних навичок та, окрім кінезіологічного реабілітаційного впливу, покликана виконувати і такі функиіі: психофізіологічна функція; психотерапевтична функція; реабілітаційна функція; функиія задоволення потреби в компетентності; функція самореалізації; функція спілкування. Одним з найефективніших методів
} 
анімалотерапії є іпотерапія. Відновний ефект верхової їзд для хворих базується на використанні функиії руху, який має для людини не лише біологічне, а й сочіальне значення. Іпотерапія поєднує в собі кінезітерапевтичну, фізіотерапевтичну, когнітивну дію на емоиії та психіку пацієнта, сприяє руйнуванню патологічних еферентних імпульсів. В багатьох, особливо приморських краӥнах, в т. ч. в Україні, ще з 70-х років минулого століття, активно розвивається дельфінотерапія для реабілітації дітей з посттравматичним стресовим синдромом, депресіями, емочійними розладами, захворюваннями опорно-рухового апарату та ін. Встановлено позитивний ефект фелінотерапії у дітей з енурезом, логоневрозом, неврастенією. Фелінотерапія сприяє зниженню артеріального тиску, нормалізує роботу серия, позбавляє від суглобових $і$ головних болей. Кішки прискорюють відновлення після травм, лікують внутрішні запальні захворювання. Каністерапія (лікування за допомогою собак) показана при подагрі, ревматизмі, захворюваннях печінки і сечового міхура. У каністерапії найчастіше використовуються породи собак-компаньйонів: лабрадори, коллі, мопси і навіть звичайна дворняжка. Окрім описаних методів, існує щее дуже багато методів анімалотерапї, це контакти людини з рептиліями, сон на вуликах медоносних бджіл та інші.

Ключові слова: анімалотерапія, іпотерапія, фелінотерапія, каністерапія.

Оздоровлення людей $з$ допомогою тварин називають анімалотерапією або пет-терапією (від англ. pet домашній улюбленець). Цей напрямок медицини icнував 3 прадавніх часів і в останні роки стрімко розвивається в силу об'єктивних причин зміни соціальних та геохімічних умов життя на нашій планеті (Saliienko, 2014; Verevkina, 2017). Анімалотерапія позитивно діє на всі фізіологічні сфери людини, має лікувальну сомато- та психотерапевтичну реабілітаційну дію. Розрізняють направлену анімалотерапію (використання спеціально навчених тварин за розробленими терапевтичними програмами) і ненаправлену (взаємодія $з$ тваринами у домашніх умовах) (Kirilenko, 2012). Анімалотерапія має окремі напрямки: іпотерапія (спілкування кіньми), дельфінотерапія (дельфінами), каністерапія (собаками), фелінотерапія (котами), апітерапія ( бджолами) та інші.

\section{Історична довідка}

“Анімалотерапія” відома $з$ часів Гіпократа. Але наукове обгрунтування отримала в середині XX століття, коли лікар-психотерапевт з Нью-Йорка Б. Левінсон виявив, що його улюблений пес Джинглс, присутній у кімнаті при прийомі лікарем хворих, заспокійливо діє на пацієнтів. В США анімалотерапія практикується вже понад півстоліття і дає позитивні результати. В 1792 році в психіатричній клініці Йорку (Англія) застосовували верхову їзду на конях для ефективного лікування і була розроблена спеціальна методика динамічної психіатрії (Ponomar, 2013). Останнім часом в західних країнах з'явились організації Animal Assisted Therapy (терапія 3 допомогою тварин), котрі використовують тварин для лікування хворих 3 фізичними або психічними проблемами (Verevkina, 2017). Багато 3 психіатричних клінік, як, наприклад, в Лімі (штат Огайо), схожі на тваринницькі ферми - на їхніх дворах вільно розгулюють вівці, гуси, кози, кури, кролики. У штаті Вашингтон навчають собак-поводирів для сліпих інвалідів, а також собак, які супроводжують епілептиків, собаки починають гавкати, перш ніж їхній господар відчує наближення нападу. В різних програмах на державному рівні застосовують методи анімалотерапії в роботі 3 дітьми із вродженими вадами, що страждають на аутизм, шизофренію та ін.

\section{Стан розвитку анімалотерапії в Україні}

В Україні теж існують спеціальні програми, що використовують тварин для оздоровлення людей. В Києві, Харкові, та ін. в декількох екопарках застосовують спеціальні лікувально-профілактичні та реабілітаційні програми. У нашій країні, та й в усьому світі, постійно збільшується кількість ослаблених дітей з особливими потребами - 3 ДЦП, аутизмом, синдромом Дауна, синдромом дефіциту уваги і гіперактивності, різними неврозами, порушеннями нервової системи, психічними розладами. Саме для такого контингенту анімалотерапія $\epsilon$ найефективнішою реабілітацією. Анімалотерапію у вигляді іпотерапії та каністерапії активно застосовують на Житомирщині в центрі оздоровлення “Тріумф" благодійного фонду “Берегиня Полісся” де проводять заняття для дітей, хворих на ДЦП, аутизм, нервові розлади. Апітерапію, дельфінотерапію та іпотерапію активно застосовують та розвивають: в реабілітаційному центрі "Еліта" м. Трускавця, Київському “Іпотерапевтичному центрі "Спіріт" асоціації іпотерапевтів України, кінноспортивному клубі “Петрусевич”, в близько 15 менших кінно-спортивних клубів, зокрема в Севастополі, Одесі, Полтаві, Білій Церкві, Львові (центр “Кептарик", стадіон СКА за спонсорством “Львівського блоку”), в Миколаєві, та в ін. містах, котрі можуть похвалитися позитивними результатами оздоровлення дітей. На Закарпатті є оздоровчий кінно-спортивний клуб “Сивка”. В багатьох вищих навчальних закладах медичного профілю вже ведуться дискусії щодо включення предмету “анімалотерапія" в програми підготовки студентів відповідних спеціальностей.

\section{Основні функції і методи анімалотерапії}

Методи анімалотерапії на відміну від інших реабілітаційних методик дозволяють не тільки зменшити м'язовий тонус, збільшити обсяг пасивних рухів, набути нових активних моторних навичок та, окрім кінезіологічного реабілітаційного впливу, покликана виконувати і такі функції:

- психофізіологічна функція (взаємодія з тваринами може знімати стрес, нормалізувати роботу нервової системи, психіки загалом);

- психотерапевтична функція (взаємодія людей 3 тваринами може істотним чином сприяти гармонізації їхніх міжособистісних відносин); 
- реабілітаційна функція (контакти з тваринами є додатковим каналом взаємодії особистості 3 навколишнім світом, що сприяє як психічній, так і соціальній ії реабілітації);

- функція задоволення потреби в компетентності (потреба в компетентності, що виражається формулою “я можу”, є однією з найважливіших потреб людини);

- функція самореалізації (однією 3 найважливіших потреб людини є потреба реалізації свого внутрішнього потенціалу, потреба бути значущим для інших,);

- функція спілкування (однією з найважливіших функцій, яку можуть здійснювати тварини в процесі взаємодії людини з ними - це функція партнерів спілкування).

В медико-психологічній реабілітації, особливо для дітей та підлітків, $є$ багато складових. По-перше, фізичний i емоційний компоненти. Так, їзда на коні, плавання 3 дельфінами тренує і розвиває певні групи м'язів. Безпосередній тактильний контакт з собаками, кішками $є$ для дітей потужним емоційним чинником, позитивно впливає на психіку, розвиває інтелектуально. Адже у повсякденному житті, в соціальному середовищі, діти та підлітки позбавлені контакту та уваги рідних і близьких - батьки постійно зайняті на роботі. А спілкування 3 живим світом необхідне для повноцінного розвитку дитини (Kozhyna \& Cherkasova, 2013).

Одним 3 найефективніших методів анімалотерапії $\epsilon$ іпотерапія. Відновний ефект верхової їзди для хворих базується на використанні функції руху, який має для людини не лише біологічне, а й соціальне значення (Ponomar, 2013). Основа терапії - у природніх рухах коня, що дозволяє хворому організувати та систематизувати свої рухи. Іпотерапія поєднує в собі кінезітерапевтичну, фізіотерапевтичну, когнітивну дію на емоції та психіку пацієнта, сприяє руйнуванню патологічних еферентних імпульсів. Тварина виступає в ролі “терапевтичного посередника" для хворого, передаючи йому від 90 до 100 різнонаправлених рухових імпульсів. Ця дія викликає у відповідь спонтанну реакцію хворого, створюючи своєрідний діалог 3 конем. Верхова їзда сприяє також формуванню особистості: вмінню критично оцінювати свої дії, розвитку емоційно-вольової сфери. Цей позитивний вплив верхової їзи використаний дослідниками, зокрема при лікуванні вертеброгенного больового синдрому при остеохондрозі хребта (Ponomar, 2013). У деяких країнах іпотерапія (від грец. Нірро - кінь) є офіційно визнаним методом лікування. В основу дії були покладені два основні чинники: психогенний і біомеханічний. Основоположником розробки сучасних методик іпотерапії вважається норвезьська лікарка Елізабет Бодікер, котра досить ефективно займалась реабілітацією інвалідів після травм. Багатогранність впливу іпотерапії, одночасне поєднання повторних різноспрямованих рухів тіла, масаж внутрішньої поверхні ніг, позитивний психотерапевтичний ефект від спілкування хворої дитини 3 конем визначають унікальність іпотерапії.
Загальний принцип ліквідації порушень при ДЦП полягає у тому, що спочатку пасивно, а потім пасивно-активно окремим частинам тіла пацієнта надаються положення, протилежні до існуючих установок. Важливо зруйнувати механізми мимовільного одночасного руху в ураженій і здоровій кінцівках, які характерні для цього захворювання. Кінь, який іде, передає вершнику понад сто різних рухів. Перевага іпотерапії полягає у можливості багаторазового повторення всіх цих рухів, при цьому вдається уникнути, як при заняттях на тренажерах, докучання - кінь не може набриднути. Повторювані коливальні рухи тіла носять діагональний характер у вигляді чергування, розтягування, стискування, обертання окремих частин тіла. Різноспрямовані дії, які виконує вершник, допомагають йому зрозуміти рух, навчитися регулювати м'язовий тонус і набути необхідних моторних навичок (Ponomar, 2013). Виконання вправ, спрямованих на випрямлення тулуба, дозволяє провести корекцію рівноваги і рухової активності відповідно до фізіологічного розвитку дитини. Механізм дії верхової їзди більш інтегрований за впливом на центри координації головного мозку, ніж при ЛФК, оскільки в процесі верхової їзди в роботу включаються всі основні групи м'язів тіла на рефлекторному рівні. Людина, сидячи на коні, рухаючись разом з ним, інстинктивно прагне зберегти рівновагу, щоб не впасти 3 коня, і тим самим спонукає до активної роботи як здорові, так і уражені м'язи, не помічаючи цього. Під впливом фізичних вправ на коні відбувається посилення функції вегетативних систем. Температура тіла коня перевищує людську на 1,5-2 градуси. Тому при безпосередньому контакті $з$ конем відбувається вплив інфрачервоних променів на м'язи та суглоби ніг і тазу (Epifanov \& Epifanov, 2013).

Принциповими елементами іпотерапевтичного впливу $є$ кілька складових тренувально-оздоровчої методики, а саме: особливості позиції вершника (положення, посадки вершника) на коні, характер руху коня, а також тривалість власне процедури (перебування на коні). Позиція вершника на коні залежить від фізичних можливостей та вмінь дитини, а також визначається кожною конкретною застосовуваною методикою. Вправи можуть виконуватися як і просто на коні (який стоїть), так і під час його руху. Характер руху коня на манежі та його зміна визначається інструктором згідно 3 основними кінцевими цілями застосування іпотерапії та може бути у вигляді алюру, кроку, рисі, кентеру, галопу, кар'єру та ін. Тривалість сеансів (перебування на коні) варіюється залежно від діагнозу та фізичної підготовки вершника та в середньому становить - 20-30 хв. Заняття проводиться в три етапи: початковий (адаптаційний), реабілітаційний і заключний (формування довготривалої пам'яті, збереження засвоєної навички), котрі включають: посадку (на коня); адаптацію вершника до тварини та тварини до вершника; об'їжджування тварини (за участі тренера-інструктора); процедурний етап (вправи, варіативні елементи програми); спроби самостійного керування конем.

В багатьох, особливо приморських країнах, в т. ч. в Україні, ще 3 70-х років минулого століття, активно 
розвивається дельфінотерапія для реабілітації дітей 3 посттравматичним стресовим синдромом, депресіями, емоційними розладами, захворюваннями опорнорухового апарату та ін. (Lukina, 2007; Galich, 2011). Дельфінотерапія - унікальний метод використання морський ссавців - дельфінів в оздоровленні людей. У своєму спілкуванні дельфіни використовують різні види звуків, що нагадують свист, тріск, потьохкування, виття. Звуки, що видаються ними, охоплюють незвичайно широкий спектр частотних характеристик - від інфразвукових до звукових і ультразвукових. Їхні сигнали можуть бути імпульсними і неперервними та по-різному впливають на організм людини (Chuprikov et al., 2011). Вважається, що для орієнтації дельфіни використовують більш низькі і тривалі сигнали, а для розпізнавання - сигнали більш високої частоти. Імпульсні сигнали супроводжують ехолокацію. Череп і м'які тканини голови людини концентрують звукові коливання і відіграють роль акустичного прожектора і звукової лінзи, що забезпечує складний фізіотерапевтичний вплив на нейрофізіологічні процеси в організмі людини. Ультразвукові хвилі є важливою складовою в лікувальному процесі дельфінотерапії. Відомо, що дельфіни унікальні тим, що здатні до міжвидової комунікації, легко і радісно йдуть на контакт. Ці тварини тонко відчувають настрій людини, в результаті чого знаходять індивідуальний підхід до партнера. Ігри з дельфінами настільки цікаві і в той же час природні, що люди, роками намагаються вилікуватися від нервових недуг, незабаром відчувають себе набагато краще. Широко досліджується роль ультразвукового впливу дельфінів (Lukina, 2007). Ультразвук покращує потік ферментів і гормонів через мембрани клітин, чим викликає метаболічний лікувальний ефект. Ще одна незаперечна перевага дельфінотерапії - гідромасаж внутрішніх органів і шкірних покривів. Секрет ось у чому: при русі тварини створюються області турбулентності - різноспрямовані потоки води, модульовані хвостовим плавцем. Досліджено, що курс дельфінотерапії (Romanchuk et al., 2011) позитивно впливає на функціональний стан серцево-судинної системи у дітей, які мають різні захворювання центральної нервової системи (Galich, 2011). Це ж дослідження показало, що заняття 3 дельфінами позитивно вплинуло на вегетативне забезпечення серцевої діяльності. Помічений позитивний вплив купання з дельфінами на вагітних жінок. Сполучення дельфінотерапії та психологічного тренінгу значно знизило ускладнення вагітності та пологів (Galich, 2011).

Активно розвивається фелінотерапія. В ході проведення досліджень для Міністерства охорони здоров'я США група експертів віднесла кішок до групи “засоби, що застосовуються проти стресових станів". Встановлено позитивний ефект фелінотерапії у дітей 3 енурезом, логоневрозом, неврастенією. Значне поліпшення стану відчувається у дітей, хворих на ранній дитячий аутизм і ДЦП, розумову відсталість (Kushnir, 2017). Котяче муркотіння лікарі порівнюють $з$ ультразвуковою терапією. Діапазон від 27 до 44 герц, в якому муркають кішки, сприятливо впливає на нервову систему людини, поліпшує мозковий кровообіг, нор- малізує тиск і стабілізує серцевий ритм (Kirilenko, 2012; Dudar \& Husjainov, 2015). Вчені $з$ Північної Кароліни, які досліджували звуки сімейства котячих, 3'ясували, що муркотіння допомагає загоювати рани i зміцнювати кістки. Відомо багато випадків, коли кішки запобігали серцевому нападу або допомагали при гіпертонічному кризі, рятуючи господаря від інсульту. Вони не відходили від свого господаря по декілька годин, нічого не пили і не їли, старанно муркотіли i заспокоювалися тільки тоді, коли хворому ставало краще. Фелінотерапія сприяє зниженню артеріального тиску, нормалізує роботу серця, позбавляє від суглобових і головних болей. Кішки прискорюють відновлення після травм, лікують внутрішні запальні захворювання. Коти - це свого роду ідеальні енергоінформаційні прилади. Вони чудово вміють вгадувати хворі місця свого господаря. Спілкування з ними зміцнює імунітет. Низькочастотні струми у кішок виробляються завдяки тертю шерстинок одна об іншу. Ряд експериментів показав, що найкраще кототерапія допомагає при запаленнях суглобів і гінекологічних захворюваннях. В останньому випадку кішку досить посадити на низ живота i, погладжуючи, сидіти так близько 20 хвилин.

Собака - прекрасний лікар і помічник при деяких (діабет, епілепсія) недугах, стресі, самотності та гіподинамії. Чутливість собак до змін настрою господаря, їхн відданість здатні допомогти при багатьох душевних переживаннях. Крім того, собаки виступають у ролі тренера - необхідність щоденних прогулянок із собакою гарантує рухову активність на свіжому повітрі. Каністерапія (лікування за допомогою собак) показана при подагрі, ревматизмі, захворюваннях печінки і сечового міхура. Існує вправа, при якій необхідно притискати підошвову частину стопи до тварини. Суть методу полягає в тому, що на ногах $є$ неймовірна кількість нервових закінчень, що відповідають за роботу внутрішніх органів. В результаті стимуляції цих закінчень нормалізуються обмінні процеси, поліпшується кровообіг і проходження нервових імпульсів (Kozhyna \& Cherkasova, 2013). У каністерапії найчастіше використовуються породи собаккомпаньйонів: лабрадори, коллі, мопси і навіть звичайна дворняжка.

Незаперечне значення має наявність вихованця в сім'ї з дитиною, що дозволяє 3 дитинства виховати такі важливі якості, як любов до навколишнього світу, природи, здатність довіряти, ділитися. В цьому плані себе добре зарекомендували добродушні спанієлі, рухливі такси, а собаки великих порід (сенбернар, ньюфаундлен, боксер) стають відмінними няньками і охоронцями. Головне - переконатися у відсутності агресії тварини. Це допоможуть зробити в спеціальному кінологічному центрі, де собака пройде ряд тестів.

Окрім описаних методів, існує ще дуже багато методів анімалотерапії, це контакти людини з рептиліями, сон на вуликах медоносних бджіл та інші.

В сучасних умовах зміни клімату на планеті, мутацій багатьох інфекцій, геологічних та урбанізаційних потрясінь настав час серйозно привернути увагу науковців та фахівців 3 реабілітації людини до ви- 
вчення та ширшого впровадження анімалотерапії і підготовки фахівців з вказаних методів у вищих навчальних закладах.

\section{References}

Verevkina, O.V. (2017). Animaloterapija kak innovacionnyj i perspektivnyj metod psihologicheskoj raboty. Jelektronnyj nauchnyj zhurnal "APRIORI. serija: gumanitarnye nauki" http://apriorijournal.ru/journal-gumanitarnie-nauki/id/1648 (in Russian).

Galich, S. (2011). Vozmozhnosti del'finoterapii kak jelementa perinatal'noj ohrany vnutriutrobnogo rebenka. Z turbotoju pro zhinku, 1, 42-45 (in Russian).

Dudar, A.I., \& Husjainov, T.M. (2015). Vozmozhnosti ispol'zovanija domashnih zhivotnyh pri rabote s klientom $\mathrm{v}$ sovremennoj social'noj rabote i psihologii. Gumanitarnye nauchnye issledovanija. 3, [Jelektronnyj resurs]. Rezhim dostupa: http://human.snauka.ru/2015/03/10117 (in Russian).

Epifanov, V.A., \& Epifanov, A.V. (2013). Reabilitacija v nevrologii. M. GJeOTAR Media, 329-330 (in Russian).

Kirilenko, M. (2012). Chetveronogie druz'ja v nashem dome i nashej dushe. M. Kirilenko. Farmacevtpraktik. 7(8), 58-59 (in Russian).

Kushnir, O.V. (2017). Pukhnasti likari. [Elektronnyi resurs]. Bukovynskyi derzhavnyi medychnyi universytet. ofitsiinyi sait VNZ. Test, i hraf. dani. Rezhym dostupu http://www.bsmu.edu.ua/uk7news/digest/2783piihnasti likari. (Data zvernennia 27.02.2017). Nazva z ekrana (in Ukrainian).

Kozhyna, A.M., \& Cherkasova, O.O. (2013). Kanisterapiia $\mathrm{v}$ systemi reabilitatsii tryvozhnykh i depresyvnykh rozladiv u pidlitkiv. Materyaly naukovopraktychnoi konferentsii "Model psykhosotsialnoi re- abilitatsii ditei $\mathrm{z}$ riznymy psykhichnymy ta povedinkovymy rozladamy", Kharkiv, 79-81 (in Ukrainian).

Lukina, L.N. (2007). Del'finy v sisteme psihofizicheskoj reabilitacii ljudej. Sevastopol'. NPC “AKOSI - Gidrofizika" (in Russian).

Ponomar, N.V. (2013). Vlijanie ippoterapii na hronicheskij vertebrogennyj bolevoj sindrom. Vseukrainskyi forum neiroreabilitatsii ta medyko-sotsialnoi ekspertyzy. pershyi mizhnarodnyi konhres, 28-29 berez. r. K. [B. r.]. 27 (in Russian).

Romanchuk, O.P., Vasylevska, N.Iu., Sorokin, M.Iu., \& Podhorna, V.V. (2011). Vplyv delfinoterapii na funktsionuvannia sertsevo-sudynnoi systemy ditei $\mathrm{z}$ riznymy urazhenniamy TsNS. Medychna reabilitatsiia, kurortolohiia, fizioterapiia, 3, 10-13 (in Ukrainian).

Saliienko, M.Sh. (2014). Animaloterapiia. Osnovni likuvalni vlastyvosti domashnikh tvaryn. 11 Ukrainskyi naukovo-medychnyi molodizhnyi zhurnal, 4(4), 267 (in Ukrainian).

Sarapulova, Ye.H., Kucheriavyi, I.T., \& Kuprykov, S.I. (2015). Tsinnyi dosvid animaloterapii. Aktualni problemy navchannia ta vykhovannia liudei $v$ intehrovanomu osvitnomu seredovyshchi u svitli realizatsii konventsii OON pro prava invalidiv. tezy dop. XV nauk.-prakt. konf. (m. Kyiv, 18-19 lystop. 2015 r.). Kyiv. Un-t "Ukraina", 240-241 (in Ukrainian).

Syvyk, H.Ye. (2013). Animaloterapiia u roboti z ditmy z rozladamy spektru autyzmu. Zbirnyk naukovykh prats Kamianets-Podilskoho natsionalnoho universytetu imeni Ivana Ohiienka. Seriia sotsialno - pedahohichna. Kamianets-Podilskyi. Medobory 2006, 23(3), 287295 (in Ukrainian).

Chuprikov, A.P., Galich, S.R., \& Shpatakovskaja, G.V. (2011). Psihologicheskie treningi i delfinoterapija $\mathrm{v}$ optimizacii techenija perinatalnogo perioda. Perinatologija i pediatrija, 4, 22-24 (in Russian). 